\title{
Flexibility and pragmatism in promoting health: an experience of synergy between health and religion in the Islamic Republic of Iran
}

\author{
C. Adams ${ }^{7}$ and A. Manenti ${ }^{1}$
}

$$
\text { كريستين آدمز، أمبروجو مانية فينتيز المعنيز الصحة: خبرات حول التآزر بين الصحة والدين في جمهورية إيران الإسلامية }
$$

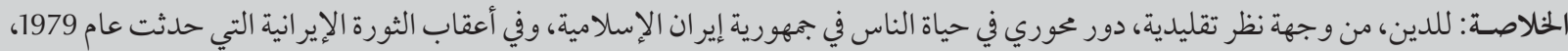

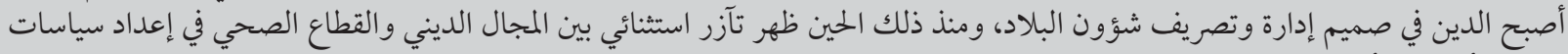

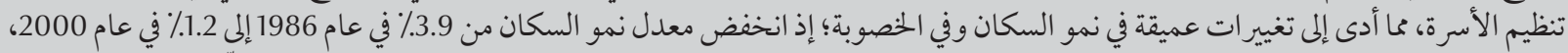

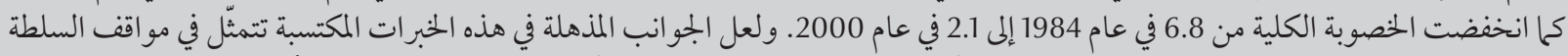

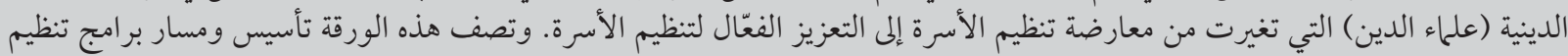

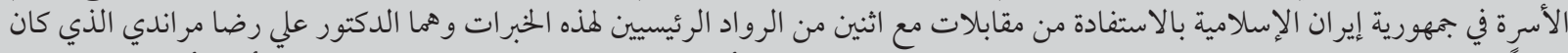

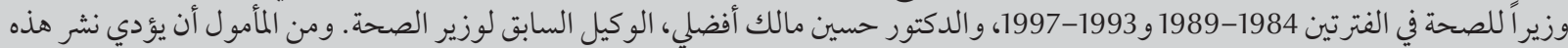

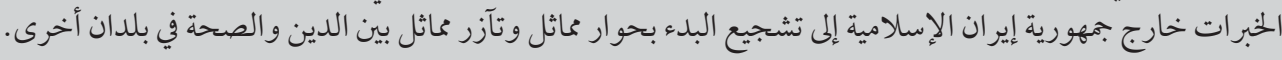

ABSTRACT In the Islamic Republic of Iran, religion has traditionally played a central role in the lives of the people. Following the Islamic Revolution in 1979, it has also become integral to the country's governance. Since the Revolution, an exceptional synergy has arisen between the domain of religion and the health sector in the development of family planning policies, which have resulted in dramatic changes in population growth and fertility: the population growth rate decreased from 3.9\% (1986) to 1.2\% (2000) and total fertility from 6.8 (1984) to 2.1 (2000). The extraordinary aspect of this experience is that the position of religious authorities changed from one of opposition to one of active promotion of family planning. This paper describes the establishment and course of family planning programmes in Iran and makes use of interviews with two main protagonists of this experience (Dr Alireza Marandi - Minister of Health 1984-1989, 1993-1997; Dr Hossein Malekafzali - former Deputy Minister of Health). It is hoped that dissemination of this experience outside of the Islamic Republic of Iran will encourage the development of similar dialogue and synergy between religion and health in other countries.

Flexibilité et pragmatisme dans la promotion de la santé : une expérience de synergie entre la santé et la religion en République islamique d'Iran

RÉSUMÉ En République islamique d'Iran, la religion a traditionnellement joué un rôle central dans la vie de la population. Après la Révolution islamique de 1979, elle est aussi devenue partie intégrante de la gouvernance du pays. Depuis lors, une synergie exceptionnelle s'est dégagée entre le domaine de la religion et le secteur de la santé pour l'élaboration des politiques de planification familiale, ce qui a conduit à des changements radicaux en termes de croissance démographique et de fécondité : le taux de croissance démographique a diminué, passant de 3,9\% $(1986)$ à 1,2 \% (2000) et le taux de fécondité total est passé de 6,8 (1984) à 2,1 (2000). La position des autorités religieuses, qui a évolué d'une attitude d'opposition à une promotion active de la planification familiale, représente l'extraordinaire caractéristique de cette expérience. L'article décrit l'élaboration des programmes de planification familiale et leur mise en œuvre en Iran et exploite des entretiens avec les deux principaux protagonistes de l'expérience : Dr Alireza Marandi, ministre de la Santé de 1984 à 1989 et de 1993 à 1997, et Dr Hossein Malekafzali, ancien vice-ministre de la Santé. L'objectif est d'encourager l'instauration d'un dialogue et d'une synergie similaires entre la religion et la santé dans d'autres pays grâce à la diffusion de cette expérience hors de la République islamique d'Iran. 


\section{Introduction}

"Every realistic person is a visionary" Federico Fellini

That health is a fundamental right of every human being is an ideal consistent with the teachings and values of Islam. Health is honoured in the holy Quran and in countless hadith, the sayings and actions ascribed to the Prophet Mohammad (PBUH), as second only in importance to faith. The preservation of health is also implicit in Islamic law's emphasis on the protection of the five essential needs of faith, life, progeny, property and mind. Based on these principles, the Amman Declaration states that individuals, governments and organizations have the responsibility to value, promote and protect health, as a blessing from God, through positive behaviour, appropriate community development and the provision of safe working conditions and environments [1].

The Government of the Islamic Republic of Iran formally recognizes the right of all Iranians to health and to unimpeded and equal access to health care services. In this Islamic state, religious values and traditional institutions have shaped the formation and implementation of relatively progressive health and social policies. Primary health care, together with broad socioeconomic improvements in rural areas, has been supported by the Iranian government largely because its fundamental principles accord with doctrinaire Islamic concerns about equity and universal participation. Indeed, Iranian clerics have legitimated and promoted health policies through formal religious rulings (fatwa), the mosque network and Friday prayers, with a far-reaching impact on social attitudes and behaviour.

The possibility for religion to be a positive ally in health policy is well exemplified by the Islamic Republic's family planning programme. Revived in 1989 with the essential support of Imam Khomeini as well as many senior authorities, this programme has effected a dramatic reduction in the country's total fertility rate, from 6.8 in 1984 to 2.1 in 2000 [2]. Upheld as a role model for other Islamic and developing countries, the Islamic Republic of Iran's highly successful birth control programme is the outcome of a profound shift in government policy that took place in the late 1980s. This significant turnaround from the early revolutionary regime's pronatalism indicates that religious rulings and government policy in the Islamic Republic can be responsive to new and emerging exigencies. The history of family planning in the Islamic Republic of Iran furthermore confirms that in such countries where religion provides meaning and direction in all spheres of life, a positive synergy between health and religion is integral to successful policy formation and implementation.

\section{Historical overview of family planning policy in Iran}

\section{Under the Shah}

In the early 1960s, the government of Imperial Iran tended towards a pronatalist policy, perceiving the country's growing population as a form of protection against its neighbours and as supporting the Shah's vision of establishing Iran as a regional power [3]. But in 1966, with the announcement of the results of the second national population census, government officials realized the need for a national family planning programme [4]. With the goal of promoting the "physical, mental, social and economic welfare of families and in consequence that of society" [5], the programme began the following year with great publicity and political support. It also received financial and technical assistance from the United States Agency for International Development and other international agencies which supported the Shah's interest in a specific model of development. The family planning programme was soon accorded an important place in the Ministry of Health. Contraceptives, primarily the contraceptive pill, were distributed through public clinics and a mass media campaign promoting family planning was conducted in the early to mid 1970s as concern heightened about the adverse effects of population growth on the national economy.

Despite its extensive resource allocation and social marketing activities, however, the Shah's family planning programme effected relatively modest achievements [6]. Its predominant focus was the urban population, with women targeted as the major recipients of services even though traditional contraceptive methods (notably azl, or withdrawal) were male-oriented [7]. In 1977, at the peak of the promotion of family planning, $37 \%$ of married women were practising contraception, $24 \%$ of whom were using modern methods [8]. And although in the period 1966-1976, there was a decline in both population growth (from $3.1 \%$ to $2.7 \%$ ) and fertility (from a total fertility rate of 7.0 to 6.3), the actual contribution of the family planning programme is debatable:

The decline was largely urban, amounting to about four children per married woman in Tehran, somewhat less in smaller cities, and very little in rural areas. It closely paralleled the large increase in primary school participation. There is no evidence that the family planning programme or the Family Protection Act, both instituted in 1967, accelerated the decline; certainly neither caused its onset [3].

The context in which the family planning programme was launched certainly did not favour its success. The majority of the population at that time was rural-based, illiterate and very traditional. Infant mortality was high and the absence of a social security system meant that high fertility had economic as well as religious value. Early marriage was encouraged and the birth of a large 
number of children, especially boys, was a source of pride and prestige and also economic security for most Iranian women who could easily be divorced if they were unable to produce a son [9].

These cultural and social factors which curtailed the successful implementation of family planning activities nonetheless received little attention from the programme's technocrats. Nor did the programme attempt to establish strategic links with religious leaders and low-profile political and professional organizations and community leaders who may have provided it with longerterm public credibility and support [3].

A further complication was the affiliation of the programme with the Iranian Women's Organization, led by the Shah's sister, Princess Ashraf. This alliance was to implicate the family planning programme in the promotion of the controversial Family Protection Law, the aims of which included raising the age of marriage and curtailing the right of men to multiple marriages and to divorce [10]. These highly sensitive reforms - and by association, therefore, the family planning programme-were strongly opposed by many religious leaders and their followers. Numerous religious leaders preached at their Friday sermons that family planning was an imperialist plot to subjugate Muslim countries by limiting their populations and hence should be denounced [7]. And although contraception (particularly azl) had generally been understood to be permitted by Islam [9], it began to be denounced by some clerics as haram (religiously prohibited). Significantly, at no time during its 12-year history did the Shah's family planning programme make any official effort to obtain a formal ruling in support of contraception and family planning from the country's senior religious leaders [3]. In fact, the only fatwa concerning the permissibility of contraceptive use issued by an Ayatollah inside Iran before the Islamic Revolution is that given by the late Ayatollah Baha-ud-Din Mahallati of Shiraz, issued in 1964 prior to the inauguration of family planning programme. It read: "Various methods of pregnancy control are not prohibited by religious laws as long as their effect is temporary and does not make women sterile" [9]. This highly positive fatwa given by a relatively senior religious leader who was aligned with Imam Khomeini in his 1961 revolt against the Shah and also deeply involved in events leading to the Islamic Revolution, reveals that contrary to representations in the Western media, the politically minded ulama (religious scholars) who emerged as the leaders of the Islamic revolution were by no means against family planning [3].

\section{After the Revolution}

In the new regime of the Islamic Republic of Iran, revolutionary Shiite clerics sought to establish a new direction independent of external influences. The practices and motives of the family planning programme, closely identified with the Shah's regime and particularly Princess Ashraf, were therefore viewed with suspicion. Few people across the political spectrum saw population and high fertility as serious problems for an oil rich country like the Islamic Republic of Iran. Technocrats emphasized instead the limiting variables of underdevelopment and dependency on the Western imperial order [9]. Moreover, in the new and dramatically changed social and cultural environment that encouraged early marriage, domesticity and motherhood - the legal minimum ages of marriage were lowered to 13 and 15 years (from 15 and 18 years) for girls and boys respectively, with marriage for girls at an earlier age left to judicial discretion based on an assessment of a girl's maturity [10], and strong economic and social incentives for early marriage and reproduction were introduced-, personnel in the family planning programme as much as the general public interested in using its services were uncertain about the permissibility of contraception and family planning.

Population as a policy matter was soon dropped from the government's agenda. The Family Planning Council was dissolved and the family planning programme officially discontinued not long after the revolution in early 1979 [6]. Religious leaders emphasized marriage and family formation as essential Islamic virtues and the government was urged to adopt economic policies that would encourage early marriage. Yet the widespread impression that the Islamic clergy were unanimously and vehemently opposed to family planning and that all services were suspended after the revolution is only partly true. Senior personnel in the Ministry of Health who continued to be concerned about the health impact of high population growth sought rulings on the permissibility of contraceptive use from Imam Khomeini and three other grand Ayatollahs in the first year following the revolution [9]. The subsequent rulings clearly indicate that senior religious leaders were not opposed to birth control through contraception as a matter of individual choice. In 1980, Imam Khomeini wrote [9]:

Prevention of pregnancy is not forbidden. As long as it is done with the consent of the couple, does not expose them to any harm, or require action inconsistent with religion, it is permissible.

These numerous rulings meant that in spite of the fact that there was no official programme, the Ministry of Health (which became the Ministry of Health and Medical Education in 1986 following the integration of two ministries) was able to continue to provide basic family planning services and free contraception on demand via its family and school health clinics throughout the period 1979-1989 [3].

The early years of the Islamic Republic were largely consumed with stabilizing the regime and refining its position on economic and social 
matters. Emphasizing equity, the new Constitution of the revolutionary government gave priority to supporting the mostaz'afin, the disadvantaged or oppressed, through the provision of basic amenities such as food as well as universal access to basic health care and education.

With the beginning of the eightyear war with Iraq in September 1980, the matter of the Islamic Republic's large and rapidly growing population assumed new significance. War propaganda presented the country's populace of circa 40 million as a major source of military strength and national security and as offering a comparative advantage over Iraq. Given the country's isolation, not least the international economic embargo imposed subsequent to the American hostage crisis, the creation of a "twenty million man army" ready to fight for the Islamic Republic of Iran and the revolution was vital and became a national slogan early in the war [6].

Rising casualties and relentless warfare also led many middle-aged couples to have more children to replace those whose loss they anticipated [6]. In addition, the universal rationing programme introduced as part of the national war effort provided tangible economic incentives for higher fertility, with larger families entitled to a better share of both basic commodities and highly prized modern consumer items. Couples as well as the government had good reason to prefer high fertility and large families.

Concurrent with the prevailing pronatalist policies was a rapid decline in infant mortality-from 114 per 1000 live births in 1975 to 51 in 1985 [2] _ partially attributable to the nationwide network of primary health care facilities established by the Islamic state. The demographic consequences of these developments became apparent with the publication of the 1986 general census results indicating an average annual population growth rate of $3.9 \%$ in the preceding decade and the creation of a huge cohort of children [2].
The country's unexpected escalation in population to 49.3 million, an increase of approximately 14 million in the decade 1976-1986, was initially hailed by incumbent Prime Minister and other leaders of the Republic as a "God sent" gift. The then Speaker of Parliament claimed that the country could and should aim at a population of 200 million [3].

But as the detailed results of the census were made available and their short- and long-term implications for the war-shattered economy became evident, public euphoria shifted to private concern, especially among ministers in the Iranian government. The Planning and Budget Organization, the national agency responsible for the monitoring and allocation of the government's financial resources, had collected extensive data on a range of issues in order to prepare the republic's First Five Year Plan of Development, due to be implemented with the cessation of war. These figures confirmed the insufficiency of the country's dwindling resources, further diminished by the 1986 plummet in oil prices, to meet not only the huge cost of ongoing warfare but also, with the impending end of hostilities, to rebuild war-torn regions and provide the rapidly growing population with the generously subsidized social and welfare services enshrined in the country's Constitution.

Senior officials in the Ministry of Health and Medical Education were also very aware of this disjunction between the government's commitments and its resources. And yet despite the fact that statistics indicated the grave consequences of rapid population growth for the Iranian economy, the position of pro-natalism fostered by the war with Iraq remained publicly predominant. Many of the incumbent politico-religious leaders had been among the most outspoken opponents of the Shah's family planning programme and continued to call for the birth of an Islamic generation. And while religious rulings permitted the private use of contraceptives by consenting couples, the idea of a national policy encouraging population control was controversial.

\section{The revival of family planning}

The appropriateness of government leadership in fertility control is a qualitatively different matter from the private use of contraceptives by consenting couples. Hence, while statistics plainly demonstrated the need for a national population policy, public discussion was limited by overriding concerns about how politico-religious leaders, traditionally pro-natalist, would respond to this issue.

In this context of widespread concern yet general reluctance to speak about the need for the re-institutionalization of family planning, the then Minister of Health (in 1984-1989 and later in 1993-1997), Dr Alireza Marandi, together with a few people in the health sector and supported by the Planning and Budget Organization, began behind-the-scene discussions within the government and with prominent religious scholars. While he sought to raise awareness about the importance of the population issue for the development of the nation, his main emphasis was on the health consequences of unchecked population growth for children, their mothers and families.

Dr Marandi's determined advocacy and his personal and professional commitment to the importance of and need for family planning were crucial to convincing the leadership of the Islamic Republic that responsible parenthood and family planning did not run counter to religious beliefs but were an integral part of them. He, among others, was able to establish a dialogue with Imam Khomeini (Supreme Leader at that time) which was essential for the promotion of an effective family planning programme that had the support of the clergy. The consensus (or more accurately, the initial non-dissent) opened doors to a wide discussion about this 
matter in Iranian society and to the progressive implementation of the Ministry of Health's family planning policies.

Together with Dr Marandi, Dr Hossein Malekafzali (deputy Minister of Health at that time) contributed to this dialogue with senior religious leaders, particularly emphasizing the health relevance of family planning (the summarized interviews with Dr Marandi and Dr Malekafzali which highlight their roles are available on request).

Under Dr Marandi's initiative, the Cabinet gave majority support (by one vote) for family planning in a Cabinet session held in 1988, even though the Prime Minister was reluctant to announce the event.

Later in September 1988, a threeday Mashhad seminar on population and development was jointly organized by the Ministry of Health and Medical Education and the Planning and Budget Organization. It was a predominantly professional and technocratic gathering that did not engage influential clerics outside the central government in its deliberations [3]. While seminar participants urged the government to introduce a national population policy and to integrate population factors into policy-making, these recommendations alone were insufficient to effect real change.

There seems little doubt, therefore, that it was Imam Khomeini's response to Dr Marandi's explanations and reasoning that paved the way for the re-establishment of a national family planning programme. His suggestion that there be public discussion about the matter led to a series of seminars aimed at ensuring that the proposed population policy would enjoy the support of the clergy. Family planning was singled out for special consideration and discussion by a group of prominent religious scholars and physicians attending a seminar on Islamic perspectives in medicine, organized by the Mashhad University of Medical Sciences in
February 1989. This was followed by another seminar explicitly dealing with Islam and population policy, which was held in Isfahan in April 1989 and brought together a number of eminent theologians and politically influential clergy.

To differentiate this programme from that endorsed by the Shah, it was important that family planning was reinterpreted as inherently Islamic.

The religious authorities saw as their first and primary task to dispel the myth that the population debate originated in modern Western society. Reviewing debates on the permissibility of fertility control and sponsoring research and republication of medieval Islamic works on population and contraception, they established that concern about population had preoccupied Muslim scholars long before it was discussed in the West. Thus, the authorities were able to celebrate Iran's Islamic heritage, to promote family planning, and to reinforce their independence from the West [7].

Once fit within an Islamic schema, the country's leading clerics mostly endorsed the introduction of family planning to the extent that having only the number of children for whom one can care is now consistently interpreted as an obligation of good Muslim parents [10].

From that point onwards, religious authorities, including Friday prayer leaders, came to play an active role in advocating for family planning among the general populace. Such clergy acting as Friday prayer leaders are appointed by the Supreme Leader, who has a Special Directorate in his office that usually determines the contents of weekly sermons [3].

Public support for family planning was also mobilized by the media. Articles were published on the consequences of unchecked population growth and a variety of round-table discussions and lectures on populationrelated issues were broadcast on radio and television. High- and low-ranking religious leaders participated directly in these debates.

To overcome misconceptions regarding the legality of birth control, the High Judicial Council announced in December 1988 that "family planning does not have any Islamic barrier" [9]. This official pronouncement removed all potential judicial impediments and enabled the Ministry of Health and Medical Education to set the family planning programme in motion.

Even so, some prominent clerics both within and outside the regime continued to express reservations about the urgency and/or congruency of state-sponsored population control with the basic tenets of Islam. These uncertainties were addressed when the newly established Expediency Council, an influential administrative assembly appointed by the Supreme Leader, approved family planning as a legitimate area of government activity [3].

\section{The consolidation of family planning}

In 1989, the First Five-Year Plan of Development Bill, which included the ideas and objectives of population control and family planning, was approved by the Islamic Legislative Assembly, four years before the law's eventual enactment in 1993.

The family planning programme officially inaugurated by the Ministry of Health and Medical Education in December 1989 had three important goals.

- To encourage the spacing of births with three to four years between pregnancies

- To discourage pregnancies in women below the age of 18 and over the age of 35 years

- To discourage parents from having more than three children.

The programme's overriding primary objective was to enhance the physical and social health of women and children in particular and as a consequence, 
the wellbeing of their families and wider society.

In line with these objectives, the Ministry of Health and Medical Education was given the mandate and generous resources to provide free family planning services to all married couples. Intersectoral collaboration was fostered by the establishment in 1990 of an interdepartmental Family Limitation Commission focusing on "beyond-thefamily planning" measures aimed at reducing infant mortality, promoting women's education and employment, and extending social security and retirement benefits to all workers [3].

The subsequent 1993 Family Planning Law enshrined birth control and cut subsidized health insurance and food coupons for any child after the third [3]. Population education became a component of formal curricula at all educational levels. University students, regardless of their course of study, were required to take a twocredit course on population and family planning. Family planning also became an element of adult literacy campaigns and couples planning to marry were obliged to participate in mandatory government-sponsored family planning classes before receiving their marriage license.

The law also mandated the Ministry of Culture and Islamic Guidance to ensure the active cooperation of all newspapers, filmmakers, and other artists in raising public awareness about family planning. The country's Broadcasting Organization was similarly required to develop, commission and broadcast radio and television programmes promoting family planning as a social norm. Smaller families were encouraged through such messages as "Better life with fewer children: girl or boy, two is enough", emphasizing the benefits of birth control for individual families as well as society as a whole which were publicized in bus stops, public spaces, parks, cinemas, and on children's toys and chocolate boxes $[8,11]$.
The successful and rapid implementation of the national population programme was undoubtedly facilitated by the broad-based health network established by the Islamic state. Family planning services, including the supply of contraception, are now provided free-of-charge across the country. Following the High Judicial Council's 1990 declaration that sterilization-often considered to be contrary to Islamic teachings and banned in most Islamic countries [9] — is not against Islamic principles or existing laws, vasectomies and tubal ligations have been strongly advocated and made available without charge. Although abortion remains illegal, the Therapeutic Abortion Act passed in 2005 permits the termination of pregnancy before ensoulment, that is during the first four months of pregnancy, with the parents' consent and upon confirmation of grave maternal risk and/or major fetal disorder by the Coroner's Office and three medical specialists.

These broad, multisectoral measures affected a profound impact on the total fertility rate, which fell sharply from 5.6 in 1988 to around 2.8 in 1996, a decline of $50 \%$ in eight years that was evident in rural as well as urban areas [2]. Especially significant was the narrowing in regional and urban/rural differences in both fertility levels and contraceptive usage, with some provinces in more recent years experiencing fertility below an average of two children per woman [10].

It has been noted by some demographers that a latent demand for contraception clearly existed prior to the legislation of an anti-natalist policy by the Islamic government, with almost $50 \%$ of eligible couples already using some form of contraception $[3,6]$. This possibly reflected the lowered incidence of child mortality as well as heightened economic pressures due to high rates of inflation and unemployment [5]. But while the national total fertility rate had begun to decline from 1984, this decrease was relatively small and primarily confined to urban areas, unlike the more marked, country-wide decline that followed the re-establishment of a national family planning programme [4].

General consensus attributes the tremendous success of the Islamic regime's birth control programme to the support it received from the clergy many of whom had strongly opposed the Shah's family planning programme but, after considering the historical deliberations of Muslim scholars, completely changed their opinion and became active advocates for responsible family planning. The endorsement of the reintroduction of a national population policy by Imam Khomeini in particular effectively removed ideological barriers to its implementation and, moreover, fostered the understanding that birth control is a religious as much as social duty.

\section{Conclusion}

In this debate, arguments related to population science and economic growth were not useful to productive dialogue with the clergy, being sometimes abstract and ideologically far removed from Iranian tradition and culture. By comparison, the health consequences and evident harm of unregulated population growth and a high fertility rate were more appropriate grounds through which to persuade religious authorities.

Child spacing, women's health and family prosperity have been considered important elements of religious principles and Islamic teachings that are clearly connected to the issue of family planning.

The evolution of the family planning concept and strategy in the Islamic Republic of Iran reveals the potential flexibility and pragmatism of religious rulings.

It is hoped that the dissemination of this experience outside the Islamic republic of Iran will encourage the development of similar processes of dialogue and synergy between religion and 
health in other countries, particularly those societies in which religion plays a central role traditionally, culturally, socially and politically.

Finally, it should be highlighted that the exceptionality of this experience may be used to facilitate new forms of alliance between the health sector and religious leaders. The example of family planning may serve as a model and source of inspiration when seeking to establish common ground for dialogue in such areas as environmental health, adolescent and youth health, and social determinants of health, guiding the creation of new synergies and joint efforts to address problems of health and to promote a better quality of life for Iranian people.

\section{Acknowledgements}

Special thanks are due to Dr Alireza Marandi and Dr Hossein Malekafzali for their willingness to contribute their direct testimonies to this study. The support of Dr Jalal Abbasi-Shavazi and the bibliographic research of Golareh Habibi are also acknowledged.

\section{References}

1. Health promotion through Islamic lifestyles: the Amman Declaration. Alexandria, World Health Organization, Regional Office for the Eastern Mediterranean, 1996.

2. Abbasi-Shavazi MJ, McDonald P. Fertility decline in the Islamic Republic of Iran: 1972-2000. Asian Population Studies, 2006, 2(3):217-37.

3. Mehryar A et al. Repression and revival of the family planning programme and its impact on the fertility levels and demographic transition in the Islamic Republic of Iran. ERF Working Paper 2022. Cairo, Economic Research Forum for the Arab countries, Iran and Turkey, 2002.

4. Abbasi-Shavazi MJ. The rise and fall of fertility in postrevolutionary Iran. In: Jones GW, Karim M, eds. Islam, the state and population. London, Hurst and Co., 2005:199-217.

5. Aghajanian A. A new direction in population policy and family planning in the Islamic Republic of Iran. Asia-Pacific Population Journal, 1995, 10(1):3-20.

6. Abbasi MJ et al. Revolution, war and modernization: population policy and fertility change in Iran. Journal of Population Research, 2006, 19(1):25-46.
7. Hoodfar H, Assadpour S. The politics of population policy in the Islamic Republic of Iran. Studies in Family Planning, 2000, 31(1):19-34.

8. Roudi-Fahimi F. Iran's family planning program: responding to a nation's needs. Policy brief. Washington DC, Population Referencing Bureau: Middle East and North Africa, 2002.

9. Mehryar A. Ideological basis of fertility changes in postrevolutionary Iran: Shiite teachings vs. pragmatic considerations. In: Jones GW, Karim M, eds. Islam, the state and population. London: Hurst and Co, 2005:118-56.

10. Abbasi-Shavazi MJ, McDonald P. Family change in Iran: religion, revolution, and the state. In: Jayakody R, Thornton A, Axinn W, eds. International family change: ideational perspectives. Philadelphia, PA, Lawrence Erlbaum Associates, Taylor \& Francis Group, 2007:177-98.

11. Abbasi-Shavazi MJ. Recent changes and the future of fertility in Iran. In: United Nations' Population Division, completing the fertility transition. New York, Population Division of the United Nations, 2002:425-39. 